Beata ADAMCZYK

Wydział Dziennikarstwa i Nauk Politycznych Uniwersytet Warszawski

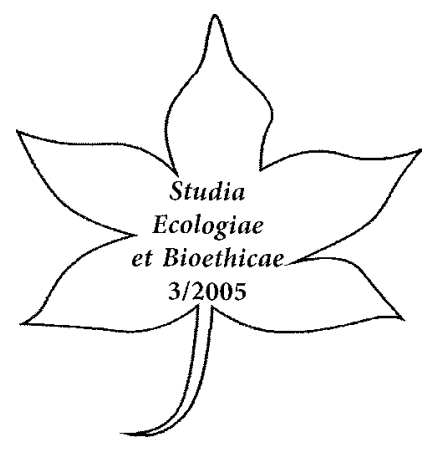

\title{
Informacja ważnym czynnikiem rozwoju gospodarstw rolnych na wsi polskiej w warunkach integracji z Unią Europejską
}

Informacja jest ważnym czynnikiem umożliwiającym aktywność polityczną i społeczną obywateli w warunkach integracji z Unią Europejską. Przedstawienie założeń strategii i realizacji działań informacyjnych stanowi ważny element analizy tego procesu. Właściwa dla obywatela informacja sprawia, że może czuć się bardziej odpowiedzialnym i bardziej wolnym ${ }^{1}$.

Konstytucja Rzeczypospolitej Polskiej zapewnia obywatelom prawo do trzech rodzajów informacji ${ }^{2}$. W artykule jest omówiony problem realizacji prawa obywateli do informacji o działalności organów władzy publicznej oraz osób pełniących funkcje publiczne (art. 61) 3 $^{3}$. Obywatel ma prawo do uzyskiwania informacji o działalności organów władzy publicznej oraz osób pełniących funkcje publiczne ${ }^{4}$. Ta ustawa nie narusza innych ustaw określających odmienne zasady i tryb dostępu do informacji publicznych. Obywatel realizując swoje prawo do informacji może

1 Na podstawie: Do dziennikarzy zagranicznych, Watykan 5 lutego 1981, (W:) Jan Pawel II naucza o środkach komunikacji publicznej, Warszawa 1989, s. 54.

2 Prawo do informacji o sobie samym (art. 51 ust. 3), realizowane przez ustawę o ochronie danych osobowych (Dz,U. $1997 \mathrm{nr} 133 \mathrm{poz} .883$ ). Prawo do informacji o stanie i ochronie środowiska (art. 74 ust. 3), realizowane przez rozporządzenie ministra środowiska $z$ dnia 1 października 2002 r. w sprawie udostępniania informacji o środowisku (Dz. U. $2002 \mathrm{nr} 176$ poz. 1453).

3 Realizowane przez ustawę o dostępie do informacji publicznej (Dz.U. $2001 \mathrm{nr} 112$ poz. 1198).

4 Prawo to obejmuje również uzyskiwanie informacji o działalności organów samorządu gospodarczego i zawodowego, a także innych osób oraz jednostek organizacyjnych w zakresie, w jakim wykonują one zadania władzy publicznej i gospodarują mieniem komunalnym lub majątkiem Skarbu Państwa (art. 61 p.1). Ustawie o dostępie do informacji publicznej podlegają również sądy, Prokuratura. Ze względu na szczególny charakter działań odmienne zasady i tryb dostępu do informacji publicznej obowiązują w procedurze karnej (kodeks postępowania karnego). Sądy i prokuratura decydują o udostępnieniu informacji ze względu na stopień zaawansowania postępowania. Obywatel ma także prawo uzyskać informacje od osób prywatnych i prawnych, które były upoważnione do pełnienia zadań publicznych lub do gospodarowania mieniem komunalnym lub należącym do Skarbu Państwa. 
powołać się na przepisy innych ustaw lub przepisy ustawy o dostępie do informacji publicznej. Obywatel decyduje o wyborze. Całkowicie błędne jest twierdzenie, iż okoliczność, że ustawa o dostępie do informacji publicznej, jeśli nie narusza innych ustaw, powoduje, że ustawy tej nie można stosować w sytuacji, gdy zasady dostępu do informacji określa inna ustawa. Artykuł 1 ustawy zapewnił brak ograniczeń (podmiotowych i przedmiotowych) w stosowaniu ustawy o dostępie do informacji publicznej (art. 1). Ustawa o dostępie do informacji publicznych stanowi, że zasadą będzie to, że wszelkie informacje publiczne będą dostępne w Biuletynie Informacji Publicznych, a po złożeniu wniosku obywatel ma prawo dostępu do informacji, które nie zostaną umieszczone w Biuletynie. Udostępnieniu nie podlegają te informacje, które zostały utajnione.

W urzędach brakuje dostępu do dokumentu, który oficjalnie zawiera informację publiczną. Organy administracji są zobowiązane do powszechnego udostępniania takich dokumentów. Biuletyn Informacji Publicznej jest dokumentem, który powinien być powszechnie i bezplatnie dostępny dla obywatela w każdym urzędzie. Sprawdziłam, że w praktyce to nie jest realizowane. BIP jest dostępny tylko w Internecie. Należy uwzględnić, że dostęp do Internetu mają nie wszyscy obywatele lub mają w ograniczonym zakresie (np. brak dostępu do Internetu, koszty połączenia, sprzętu komputerowego). Ponieważ wszyscy obywatele mają równy dostęp do bezpłatnej informacji, organ państwowy ma obowiązek udostępnienia informacji w takiej formie, jaką określi obywatel (art. 5 i art. 10). Odmowa wydania informacji publicznej musi nastąpić w drodze decyzji administracyjnej przy zastosowaniu przepisów kodeksu postępowania administracyjnego (art. 16). Jeśli w decyzji odmownej urzędnik odwołał się do ochrony tajemnicy państwowej, służbowej, skarbowej lub statystycznej, obywatel może wnieść skargę do sądu rejonowego na zasadach przewidzianych w ustawie o Naczelnym Sądzie Administracyjnym (art. 21 i art. 22).

Ważkość prawa obywateli Unii Europejskiej do informacji publicznej wyraża się tym, że zostało zabezpieczone w traktatach ustanawiających Unię. Traktat z Maastricht dokument podpisany przez piętnaście krajów Unii Europejskiej jednoczących się w pierwszym etapie (7 lutego 1992 roku) wprowadził zasadę przejrzystości działań instytucji i organów Unii Europejskiej5. Artykuł 255 Traktatu Amsterdamskiego (2 października 1997 roku) gwarantuje każdemu obywatelowi UE, każdej osobie fizycznej lub prawnej na terenie państwa członkowskiego Unii prawo dostępu do dokumentów Parlamentu Europejskiego, Rady Europejskiej i Komisji Europejskiej. Na mocy Decyzji Rady Europejskiej zaczął funkcjono-

5 Prawo dostępu do informacji (Declaration on the right of access to information) zostało ogłoszone w Official Journal C 191, 29/07/1992 p. 0101.

6 Istnieje pięć wyjątków od tej zasady: interes publiczny, prywatność, tajemnica handlowa i przemyslowa, ochrona finansowych interesów Wspólnoty, ochrona poufności na życzenie osób trzecich lub państw członkowskich oraz jeden wyjątek fakultatywny - tajemnica obrad. 
wać mechanizm gwarantujący prawo publicznego dostępu do jej niepublikowanych dokumentów. We wniosku Parlamentu Europejskiego i Rady Europejskiej uzasadniono konieczność ustanowienia infrastruktury informacji przestrzennej we Wspólnocie, stwierdzając, że dobra polityka zależy od wysokiej jakości informacji oraz świadomego uczestnictwa społecznego. Celem wniosku jest umożliwienie szybkiej dostępności informacji na poziomie krajowym i wspólnotowym i zapewnienie, by informacja była dostępna publicznie ${ }^{8}$. Narzędziem do realizacji jest program INSPIRE obecnie przeznaczony do zadań ochrony środowiska, który w przyszłości może być rozszerzony o rolnictwo.

Władysław Czapliński ${ }^{9}$ stwierdzil, że zasada pierwszeństwa prawa wspólnotowego przed krajowym oznacza tylko tyle, że krajowe nie może usprawiedliwiać niewykonywania zobowiązań międzynarodowych. Nie podważa to nadrzędnego charakteru konstytucji. Z pewnością ważność środków prawnych podejmowanych przez Wspólnotę może być oceniana wyłącznie w świetle prawa wspólnotowego. Nie można podważać skuteczności tego prawa, powołując się na sprzeczność normy wspólnotowej z konstytucją. Polska wypełnia swoje zobowiązania międzynarodowe, lecz to nie oznacza, że konstytucja jako najwyższy akt polskiego prawa, nie ma charakteru nadrzędnego ${ }^{10}$. Prawo wspólnotowe obowiązuje wprost, jeżeli tylko spełnia wymogi formalne wynikające z prawa pierwotnego ${ }^{11}$. Ochrona praw fundamentalnych jest wymogiem prawa wspólnotowego, ponieważ należą one do wspólnego dziedzictwa konstytucyjnego państw członkowskich ${ }^{12}$.

Pojęcie „Wsi” jest różnie określane w prawie polskim i unijnym ${ }^{13}$. W Polsce obszar wiejski zdefiniowano jako terytorium pozostające poza granicami admi-

7 Decyzja Rady Europejskiej 93/731/EC z grudnia 2003 roku.

8 Wniosek dotyczący dyrektywy Parlamentu europejskiego i Rady w sprawie ustanowienia infrastruktury informacji przestrzennej we Wspólnocie (INSPIRE) \{SEC(2004) 980\} / COM/2004/ 0516 końcowy - COD 2004/0175*/z dnia 23.7.2004 roku.

9 Władystaw Czapliński jest specjalistą prawa międzynarodowego publicznego i europejskiego, profesorem, dr. hab. nauk prawnych.

${ }_{10}$ Czapliński W., Unia Europejska. Prawo krajowe, wspólnotowe, unijne i międzynarodowe. Pierwszeństwo to nie nadrzędność, (W:) „Rzeczpospolita”, 6 września 2004, s. C3.

11 Zasadnicza różnica między prawem wspólnotowym a międzynarodowym. Biernat T., Wspólnota prawa. O osobliwościach systemu europejskiego, Toruń 2002, s. 92-94.

12 Czapliński W., Unia Europejska. Prawo krajowe..., s. C3; prawa fundamentalne były traktowane na innej płaszczyźnie niż pozostałe normy prawa międzynarodowego. Uważano je za zasady prawa, ale nie były częścią prawa stanowionego. Wprawdzie traktaty założycielskie Wspólnot w kilku miejscach odwołują się do praw zasadniczych (zakaz dyskryminacji, swoboda przepływu osób), nie ma sformułowanego ich katalogu, który mógłby stanowić wskazówkę dla sądów stosujących prawo wspólnotowe. Czapliński W., Zarys prawa europejskiego, s. 35.

13 Od 1 maja 2004 roku Polska przyjęła dorobek prawny Wspólnot. Szacunkowo w prawie unijnym około $40 \%$ wszystkich aktów dotyczy rolnictwa. 
nistracyjnymi miast, odmiennie niż w UE i OECD ${ }^{14}$, w których o podziale decyduje gęstość zaludnienia ${ }^{15}$.

Rozwój wsi jest w sposób szczególny brany pod uwagę w Unii Europejskiej. Prawo unijne wymaga, by rozwój wsi był zgodny i kompatybilny w państwach członkowskich ${ }^{16}$. Plany rozwoju wsi w państwach członkowskich przedstawiają zamierzone działania i ocenę zgodności i kompatybilności tych działań na rzecz rozwoju wsi. W rolnictwie muszą funkcjonować różne modele gospodarki i nie mogą być stosowane zasady gospodarki liberalnej. Nawet jeśli jest to zgodne z współczesną etyką konkurencji, stałoby się poważną kwestią polityki społecznej.

Na obecnym poziomie rozwoju cywilizacyjnego rolnictwo powinno być powiązane $z$ przemysłem. Rolnictwo towarowe nie może istnieć bez odbiorcy przemysłowego. Obecnie w Polsce rolnictwo jest w znacznym stopniu rozdrobnione. Jako formę zorganizowania proponuje się powstawanie grup producenckich ${ }^{17}$.

W związku z integracją pojawia się wiele dylematów odnośnie polskiej wsi i produkcji rolnej. W przeciwieństwie do krajów piętnastki unijnej w Polsce nie istnieje problem zbyt intensywnej produkcji rolnej. Krytycy wskażą fakt rozdrobnienia gospodarstw, zwolennicy, że wieś jest nie tylko miejscem produkcji rolnej, także społecznością, w którym utrzymywane są więzi międzyludzkie i tradycje kulturowe.

W krajach Unii Europejskiej są tereny, na których zostały osiągnięte, bądź przekroczone progi biologicznej wydolności ziemi, roślin i zwierząt. Pomimo zachęcania krajów, które w ostatnim czasie zostały członkami Unii i państw kandydujących do prowadzenia ekólogicznej produkcji roślinnej i zwierzęcej, nie obserwujemy w Unii wycofywania się z hiperintensywnych systemów tamtejszej produkcji. Do tej pory postęp gospodarczy, jaki dokonał się w Europie w olbrzymim stopniu postępował kosztem środowiska przyrodniczego. Potwierdzeniem tego stanu rzeczy w wielu krajach Europy Zachodniej jest stwierdzone przekroczenie punktu krytycznego równowagi biologicznej. Co oznacza, że niektóre zasoby potencjalnie odnawialne stały się tylko w części odnawialne lub w całości nieodnawialne. Postęp techniczny i doraźne zyski ekonomiczne były celami czołowymi. Ekonomiści oceniają, że koszty przywrócenia biologicznej równowagi tam gdzie jest to możliwe, wielokrotnie przekraczają zyski uzyskane w toku tej rabunkowej gospodarki.

14 OECD - The directorate for Education, Employment, Labour and Social Affairs - 11 lipca 1996 Polska przystąpiła do Organizacji Współpracy Gospodarczej i Rozwoju.

15 "Spóina polityka strukturalna rozwoju obszarów wiejskich i rolnictwa”, Ministerstwo Rolnictwa i Gospodarki Żywnościowej, dokument przyjęty przez Radę Minstrów w dn. 13 lipca 1999r., Warszawa lipiec 1999, s. 9.

16 Rozporządzenie Rady Wspólnot Europejskich, 17 maja 1999, Dział III „Ogólne zasady, warunki administracyjne i finansowe”, podrozdział II „Zgodność i kompatybilnośc”.

17 Ustawa z dnia 15 września 2000 r. o grupach producentów rolnych i ich związkach. Dz.U. 2000, Nr 88, poz. 983. 
Informacja ważnym czynnikiem rozwoju gospodarstw rolnych na wsi polskiej...

Zestawiając stan degradacji środowiska naturalnego w Europie Zachodniej i skutki kolektywizacji rolnictwa w krajach byłego Związku Radzieckiego, na tym tle gospodarka rolnicza w Polsce jest stabilna i prowadzona w warunkach naturalnych.

Po przystąpieniu do UE w Polsce rozpoczęto realizowanie Wspólnej Polityki Rolnej (Rural Development Plan), której ważnym przesłaniem jest umożliwienie rozwoju regionalnego. WPR opiera się na dwóch filarach: pierwszy - organizacja rynków rolnych (Common Market Organisation), drugi - środki na rozwój wsi. Obecnie częścią drugiego filaru w Polsce jest Plan Rozwoju Obszarów Wiejskich (finansowany z Sekcji Gwarancji w Rolnictwie), który jest obecnie realizowany w latach 2004-2006. Dokumentem niezależnym od PROW jest Sektorowy Program Operacyjny „Restrukturyzacja i modernizacja sektora żywnościowego oraz rozwój obszarów wiejskich". Wchodzi on w skład Narodowego Planu Rozwoju. Działania obu programów mają być kompatybilne ${ }^{18}$.

Fundusze przedakcesyjne zapoczątkowały przygotowania wsi polskiej do integracji z Unią. Służyły temu: SAPARD, Phare, ISPA ${ }^{19}$.

Przed akcesją był gotowy IACS, czyli krajowy system ewidencji gospodarstw rolnych i zwierząt gospodarskich. Był konieczny dla uzyskania dopłat bezpośrednich i na rozwój obszarów wiejskich. Obecnie w Polsce jest prowadzony system płatności bezpośrednich na lata 2004-2006, który może być przedłużony do 2008 roku. Warunkiem uzyskania dopłat jest dobra kultura rolna.

18 Rozporządzenie Rady (WE) Nr 1257/1999 z dnia 17 maja 1999 r.; Rozporządzenie Rady (WE) Nr 1260/1999 z 21 czerwca 1999; Rozporządzenie Komisji Nr 1685/2000; Rozporządzenie Komisji (WE) Nr 445/2002 z dnia 26 lutego 2002.

19 Program SAPARD składal się z siedmiu działań, organem wykonawczym była Agencja Restrukturyzacji i Modernizacji Rolnictwa. Miał na celu zróżnicowanie działalności gospodarczej na obszarach wiejskich. Realizację SAPARD-u - przyznawanie środków rozpoczęto w połowie 2002 roku - planowano na lata 2000-2006. Fundusze pozyskane z programu SAPARD umożliwiły modernizację rynku rolnego, gospodarstw, infrastruktury wiejskiej, przeprowadzenie szkoleń zawodowych. Działanie 4 „Różnicowanie działalności gospodarczej na obszarach wiejskich" wprowadzono do realizacji od 15 kwietnia 2003 roku w oparciu o Rozporządzenie Rady Ministrów (Dz.U. Nr 129, poz. 1177). Główną przesłanką Działania 4 jest umożliwienie mieszkańcom wsi czerpania dodatkowych dochodów z działalności pozarolniczej. W latach dziewięćdziesiątych restrukturyzacji wsi służyły środki także z innych programów. Po zmodyfikowaniu Phare finansowano projekty usprawniające działanie administracji centralnej i terenowej, która będzie zajmować się WPR, organizację rynków rolnych w różnych sektorach. Z Phare pochodziły środki na budowę Zintegrowanego Systemu Kontroli i Administracji (IACS - Instrumental for Structural Policies Pre-Accession) umoźliwiającego m.in. nadzór i realizację płatności bezpośrednich. W ramach ISPA zgłoszono przedsięwzięcia w dziedzinie ochrony środowiska takie jak: oczyszczalnie ścieków, poprawa jakości wody pitnej poprzez ulepszenie systemów wodociągowych i urządzeń filtrujących wodę w miejscu jej poboru. 
Od przystąpienia Polski do Unii jest wdrażany dokument programowy Plan Rozwoju Obszarów Wiejskich. Podstawą strategii PROW są jednocześnie akty prawa unijnego i dokumenty prawa polskiego ${ }^{20}$.

Sprawy ochrony środowiska skierowane do rolników obejmuje specjalny program - Krajowy Program Rolno-Środowiskowy.

Analizę Zagrożeń i Krytyczny Punkt Kontroli (Hazard Analysis Critical Control Point - HACCP) opracowano w celu rozpoznania i kontroli założeń, które mogą się pojawić w jakimkolwiek momencie procesu produkowania, składowania, dystrubucji żywności. W świetle zapisów polskich regulacji prawnych system HACCP stał się obowiązkowy bez względu na wielkość przedsiębiorstwa i rodzaj prowadzonej działalności.

Potrzeby informacyjne polskiej wsi zostały uwzględnione w rządowym „Programie Informowania Społeczeństwa. Integracja Polski z Unią Europejską”, w którym rolnicy są wymienieni jako ważna grupa społeczna ${ }^{21}$. Otwarcie PIS w dniu 4 maja 1999 roku oznaczało rozpoczęcie działań informacyjnych związanych $z$ integracją europejską dla całego społeczeństwa. Dla środowisk rolniczych były wydawane zeszyty „Forum”, pierwszy numer „Forum” ukazał się w październiku 2001 roku $^{22}$. W sprawozdaniu $\mathrm{z}$ realizacji PIS jest niewiele wymienio-

20 „Spójna polityka strukturalna rozwoju obszarów wiejskich i rolnictwa” (Ministerstwo Rolnictwa i Rozwou Wsi); „Narodowy Plan Rozwoju 2004-2006” (Ministerstwo Gospodarki, Pracy i Polityki Społecznej”; „II Polityka ekologiczna państwa” (Ministerstwo Środowiska); „Krajowy Program Zwiększania Lesistości” (MS); „Krajowa strategia ochrony i umiarkowanego użytkowania różnorodności biologicznej” (MŚ); „Zrównoważona Europa dla Lepszego Świata: Strategia Zrównoważonego Rozwoju Unii Europejskiej” (Unia Europejska); „Strategia ochrony różnrodności biologicznej UE" (UE). Skierowany jest do rolników, którzy będą mogli skorzystać $z$ oferty działań niewymagających współfinansowania ze strony przyszłego beneficjenta. Działania PROW są określone w poszczególnych Priorytetach. Aby doprowadzić do zrównoważonego rozwoju obszarów wiejskich program wspiera gospodarstwa niskotowarowe, grupy producentów rolnych, działalność rolniczą na obszarach o niekorzystnych warunkach gospodarowania (ONW), przedsięwzięcia rolnośrodowiskowe, zalesianie gruntów rolnych. W ramach PROW są wyplacane renty strukturalne. PROW jest finansowany maksymalnie w $80 \%$ przez Europejski Fundusz Gwarancji i Orientacji w Rolnictwie - Sekcję Gwarancji, co najmniej w 20\% przez budżet państwa. Sektorowy Program Operacyjny pt. „Restrukturyzacja i modernizacja sektora żywnościowego oraz rozwój obszarów wiejskich" jest przeznaczony dla: rolników, osób fizycznych lub prawnych prowadzących działalność rolniczą, grup producenckich, przedsiębiorców prowadzących działalność w zakresie przetwórstwa produktów rolnych, Lasów Państwowych, właścicieli lasów prywatnych, spółek wodnych, których statutowy cel jest związany z działalnością rolniczą. SPO ma charakter jednofunduszowy, co ogranicza zakres interwencji. Uzupełnieniem SPO są: transfery środków na rozwój infrastruktury (Europejski Fundusz Rozwoju Regionalnego - ERDF), tworzenie pozarolniczych miejsc pracy (ERDF, Europejski Fundusz Specjalny - EFS) oraz środki inwestorów prywatnych.

${ }^{21}$ „Program Informowania Społeczeństwa”, roz. V „Odbiorcy programu”, s. 15.

22 Wcześniej obszarowi rolnictwa były poświęcone zeszyty „Forum” wydawane przez pełnomocnika rządu ds. negocjacji o członkostwo RP w UE przy współudziale Krajowego Centrum Doradztwa Rozwoju Rolnictwa i Obszarów Wiejskich. 
nych przedsięwzięć informacyjnych bezpośrednio związanych z rolnictwem ${ }^{23}$. W 2003 roku na mocy porozumienia Ministerstwa Gospodarki Pracy i Polityki Społecznej z pełnomocnikiem rządu ds. referendum europejskiego została utworzona sieć Gminnych Ośrodków Informacji Europejskiej.

Organizację informacyjno-szkoleniową dla rolników podjęło MRiRW. Naczelnym organem odpowiedzialnym za kampanię w okresie przedakcesyjnym była Agencja Restrukturyzacji i Modernizacji Rolnictwa ${ }^{24}$.

W MRiRW założono rozpoczęcie działań informacyjnych w październiku 2003, zakończenie w kwietniu 2004 roku $^{25}$. W dokumentach Ministerstwa przedstawiono konkretne rozwiązania programu informowania. Założenia należy uznać za bardzo trafne np. zebrania w każdym sołectwie. Na podstawie własnych obserwacji w terenie mogę stwierdzić, że jedynymi placówkami, które mogą udzielić takich wyjaśnień są Ośrodki Doradztwa Rolniczego i jednostki terenowe Agencji Restrukturyzacji i Modernizacji Rolnictwa.

Prawo obowiązujące w Polsce pozwala obywatelowi na bezpłatne korzystanie $\mathrm{z}$ informacji urzędów państwowych (art. 15) ${ }^{26}$.

Realizacja tego prawa dla obywatela jest komentowana w środkach społecznego przekazu. W kwietniu 2004 roku prasa podała, że aby rolnicy mogli skorzystać $\mathrm{z}$ funduszy strukturalnych, musieli wypełnić szereg dokumentów. Wówczas swoje usługi w tym zakresie zaoferowały wyspecjalizowane firmy konsultingowe.

23 W latach 2000-2001 UKIE współfinansował w ramach PIS czterdzieści jeden publikacji bezpośrednio skierowanych do rolników. Na podstawie: „Realizacja Programu Informowania Społeczeństwa. Integracja Polski z Unią Europejską od 4 maja 1999 r. do 31 grudnia 2001 r.," Warszawa marzec 2002, załącznik 19 i 20, s. 85-90.

${ }^{24}$ „Biuletyn Informacyjny”, nr 5, 2003, Ministerstwo Rolnictwa i Rozwoju Wsi, Agencja Restrukturyzacji i Modernizacji Rolnictwa, s. 31. W tej sprawie Biuro Szkoleń ARiMR nawiązało współpracę z Krajowym Centrum Doradztwa Rozwoju Rolnictwa i Obszarów Wiejskich, Ośrodkami Doradztwa Rolniczego, Izbami Rolniczymi i Bankami Spółdzielczymi. Uznano, że kadra powyższych instytucji zna problemy i ma dobry kontakt ze społecznościami lokalnymi. Pierwszy etap został zrealizowany w okresie od 7 do 23 lutego 2003 roku. Celem było wyszkolenie doradców, którzy w następnych etapach będą szkolić kadrę terenową i koordynować spotkania informacyjne w solectwach. W celu koordynowania interpretacji zasad i przepisów został utworzony krajowy punkt konsultacyjny w Radomiu.

25 Uzupełnieniem szkoleń były szczegółowe informacje w broszurach z serii „Przewodnik dla Rolników" i „Biuletyn Informacyjny” wydawanych przez MRiRW oraz Krajowe Centrum DRRIOW.

$26 \mathrm{~W}$ ustawie zapisane są "dodatkowe koszty” związane z realizacją wniosku, które ma ponieść podmiot, czyli osoba, która składa wniosek. Ustawa nie wyjaśnia, czym są „,dodatkowe koszty”. W sytuacji, w której organ administracji stwierdzi, że realizując wniosek musi ponieść koszty, zawiadamia o tym wnioskodawcę. Gdy wnioskodawca nie ustosunkuje się do tej informacji (nie wycofa wniosku), organ przesyła do niego informację publiczną. Co oznacza, że ustawa o dostępie do informacji publicznej wprowadza zasadę „najpierw informacja, potem pieniądze”. Udostępnienie informacji pod warunkiem uprzedniego wniesienia opłaty jest całkowicie bezprawne. 
Firmy zarabiały na pośrednictwie wskutek niedostatecznych działań ze strony urzędów ${ }^{27}$. Problem omawiali naukowcy na konferencji ${ }^{28}$. Od sierpnia 2004 roku rolnicy już mogli korzystać z bezpłatnych usług informacyjnych udostępnionych w ARiMR. Rolnicy składali wnioski do ARiMR, która przekazywała je do wcześniej wybranych przez siebie firm spełniających wymagane warunki.

W Unii Europejskiej informacja jest traktowana jako podstawowy element rozwoju społeczeństwa ${ }^{29}$. Postęp w poszerzaniu powszechności informacji jest zagwarantowany w dokumencie Komisji Europejskiej „E-Europe: Information Society For All".

Konstytucja Rzeczypospolitej Polskiej gwarantuje każdemu obywatelowi powszechny bezplatny dostęp do informacji publicznej. Zastanawiające jest wprowadzenie po osiemnastu miesiącach od wejścia w życie ustawy ograniczeń wyszczególniających zobowiązania realizacyjne ${ }^{30}$. Prawo obywatela do informacji publicznej zostało określone w Konstytucji RP, która jest nadrzędnym aktem prawnym.

W artykule omówiłam możliwości dostępu do informacji publicznej gwarantowane obywatelowi przez prawo unijne i krajowe.

Zadania doradztwa rolniczego w Polsce są określone w ustawie o jednostkach doradztwa rolniczego z dnia 22 października 2004 roku (Dz. U. Nr 251, poz. 2507). Zgodnie $z$ obowiązującym prawem krajowym doradcy rolni są urzędnikami, czyli także ich działalność podlega ustawie o dostępie do informacji publicznej. Prawo unijne nie wyznacza określonych ograniczeń realizacji systemu doradztwa rolniczego w kraju unijnym. Obowiązkiem pracownika ODR jest zapewnienie każdemu rolnikowi podstawowych informacji o możliwościach dzialalności rolniczej w warunkach Unii Europejskiej.

27 Więclaw E., Dotacje unijne. Firmy potrzebują pomocy w przygotowaniu dokumentów. Na niewiedzy można dobrze zarobić, (W:) „Rzeczpospolita”, 13 kwietnia 2004, s. B8.

28 Materiały $z$ konferencji zostały wydane w „Lithuanii. Kwartalniku poświęconym problemom Europy Środowowschodniej" 2/2004.

29 Regulation (EEC) no 283/72 of the Council of 7 February 1972 concerning irregularities and the recovery of sums wrongly paid in connection with the financing of the common agricultural policy and the organization of an information system in this field. (W:) "Official Journal of the European Communities" 1972 L 36 s. 1 - . Instytucje Wspólnot Europejskich mają obowiązek tworzyć systemy informacyjne w celu usprawnienia realizacji wyznaczonych im zadań, np, finanse wspólnej polityki rolnej są obsługiwane przez system informacyjny.

30 Konieczne jest udostępnienie obywatelowi informacji odnoszącej się do: majątku, którym dysponują, organizacji, przedmiocie działalności i kompetencjach, osobach sprawujących funkcje i ich kompetencjach, strukturze podmiotów reprezentujących Skarb Państwa, reprezentującej państwowe osoby prawne lub osoby samorządu terytorialnego i innych jednostek organizacyjnych wykonujących zadania publiczne lub dysponujących majątkiem publicznym, zasadach funkcjonowania podmiotów: w tym tryb i czas wykonywania zadań publicznych, udostępnianie informacji o prowadzonych rejestrach i sposobach ich udostępniania. 
Informacja ważnym czynnikiem rozwoju gospodarstw rolnych na wsi polskiej...

W warunkach polskich można wyznaczyć trzy rodzaje gospodarstw: małe, czyli o niewystarczającej sile ekonomicznej, średnie o dosyć stabilnej sile ekononomicznej, wielkotowarowe o dużej sile ekonomicznej.

Prawo unijne określa, że rolnicy mogą korzystać z systemu doradztwa rolniczego na zasadzie dobrowolności.

W Polsce istnieją instytucje ODR, ARiMR, które sprawdziły się w skutecznym informowaniu w zakresie warunków stawianych rolnikom i możliwościach wykorzystania przez nich funduszy unijnych. Warunki stawiane rolnikom, którzy chcą korzystać z funduszy unijnych są zawyżone. Rolnicy ubiegający się o fundusze unijne na rozwój swoich gospodarstw powinni posiadać własne środki. Inwestycja rozpoczęta w gospodarstwie musi być finansowana w całości $z$ własnych środków. Rolnik otrzymuje zwrot części poniesionych kosztów po zakończoniu inwestycji.

Spostrzeżenia odnośnie warunków korzystania z funduszy europejskich przez rolników są przedstawione w oparciu o uwagi rolników, którzy dostosowują swoje gospodarstwa do wymagań unijnych. Opinie rolników zostały zebrane w badaniach sondażowych przeprowadzonych w gminie w województwie mazowieckim.

Na inwestycje i modernizację gospodarstwa rolnik może otrzymać maksymalnie sto pięćdziesiąt tysięcy po pokonaniu dość skomplikowanej procedury biurokratycznej. Rolnicy prowadzący duże gospodarstwa uważają, że ta kwota jest niewystarczająca na inwestycje w ich gospodarstwach. W opinii rolników kwota tej wysokości jest stosowna do rozwoju średniego gospodarstwa.

$\mathrm{Na}$ obszarach wiejskich przeważają gospodarstwa średnie, ich właściciele nie posiadają wystarczających środków własnych, które mogły być przeznaczone na inwestycje.

Dla dużych kilkusethektarowych gospodarstw bardziej opłacalne jest korzystanie z kredytów w bankach komercyjnych niż w bankach spółdzielczych ${ }^{31}$. Banki chcą pozyskać dobrego klienta i można przy wyższej kwocie kredytu wynegocjować niższą stopę oprocentowania. Rolnicy, którzy decydują się na inwestycje w swoich gospodarstwach uważają, że banki spółdzielcze mają zbyt wysokie stopy oprocentowania. Warunki, jakie banki stawiają rolnikom prowadzącym średnie gospodarstwa przy korzystaniu z kredytu, często są barierą, która powstrzymuje rolnika przed podejmowaniem modernizacji lub inwestycji w gospodarstwie. Kredyt preferencyjny dla młodych rolników funkcjonował tylko do końca 2005 roku.

31 W opinii rolników komercyjne banki umożliwiają swoim dobrym klientom kredyt o korzystnym oprocentowaniu (6-7\%). 
Dostępność do wielu z funduszy unijnych jest trudna, gdyż jest dużo ograniczeń biurokratycznych np. fundusz na.ochronę wód i gleb przyznawany na okres pięciu lat jest dosyć trudny w dostosowaniu w gospodarstwie. Trzeba rozplanować produkuję rolniczą na pięć lat, czyli wyznaczyć strukturę zasiewów na powierzchni co najmniej $1 / 3$ gospodarstwa.

Od rolnika, który korzysta z funduszy unijnych jest wymagane zachowanie dobrej kultury rolnej z uwzględnieniem wymagań ekologicznych.

W Polsce są gospodarstwa, które uzyskały certyfikat przed przystąpieniem Polski do Unii Europejskiej, gdyż wymagali tego unijni odbiorcy i do ich wymagań rolnicy musieli się dostosować. Gospodarstwa z certyfikatem musiały spełnić warunki m.in. szkolenia pracowników, odpowiednie warunki higieniczne. Certyfikat uzyskały głównie gospodarstwa produkujące na eksport. Rolnicy, których gospodarstwa uzyskały certyfikat EUROGAP ${ }^{32}$ starają się nawiązać współpracę i podjąć wspólne przedsięwzięcia.

Rolnicy prowadzący gospodarstwa niskotowarowe, jeśli chcą skorzystać z funduszy unijnych, potrzebują na początku zainwestować także własne środki (np. ze względu na koszty skompletowania mapek geodezyjnych).

Gospodarstwa wysokotowarowe i średnie wymagają informacji specjalistycznej ze względu na prowadzony przez siebie szeroki zakres swojej działalności i utrzymanie wysokiej jakości produkcji rolnej.

W Polsce nie została dotychczas opracowana strategia rozwoju rolnictwa i obszarów wiejskich z uwzględnieniem zróżnicowań rozwoju regionalnego. W obecnych warunkach polskiej wsi każdy prowadzący gospodarstwo rolnik podejmuje decyzję o ukierunkowaniu swojego gospodarstwa bez fachowego doradztwa.

Produkty rolne są bardzo ważnym elementem strategicznym dla każdego kraju, odnosi się to również do Unii Europejskiej jako związku jednoczącego większość krajów europejskich. I to jest ważnym powodem, żeby umożliwić rozwój gospodarstw rolnych na polskiej wsi i utrzymać własną produkcję rolną zabezpieczającą potrzeby kraju.

32 W certyfikacie jest przedstawiona cała droga produktu spożywczego od pola rolnika do półki w sklepie. 